\title{
SIMULAKRA SEBAGAI PEMBENTUK REALITAS PALSU
}

\author{
Martua Pahalaning Wandalibrata \\ Fakultas Ilmu Sosial dan Ilmu Politik, Universitas Mahendradatta Denpasar
}

\section{PENDAHULUAN}

Berfilsafat berarti bergulat dengan masalah-masalah dasar manusia dan membantu manusia untuk memecahkannya. Kenyataan ini tentu membawa filsafat pada pertanyaan-pertanyaan tentang tatanan masyarakat secara keseluruhan yang nota bene adalah juga bidang politik. Dan di situ biasanya filsafat muncul sebagai kritik. Dalam usaha kritisnya ini, filsafat menuntut agar segala klaim atas hak untuk menata masyarakat dapat dipertanggungjawabkan dengan benar dan tidak membiarkan segala macam kekuasaan menjadi mapan begitu saja.

Ontology merupakan ilmu cabang filsafat yang mempelajari tentang yang ada. Yang ada dalam arti ini sangatlah luas, tidak hanya yang tampak dan tidak tampak, juga melihat realitas serta eksistensi yang Ada. Pemikiran masa lampau telah banyak menyumbangkan pemikirannya mengenai hal ini, hanya saja setelah datangnya jaman postmodern banyak pemikiran-pemikiran jaman dahulu yang ditinggalkan, termasuk klaim matinya metafisika serta banyak pemikiran lainnya yang memiliki corak yang berbeda dari pemikir-pemikir sebelumnya, karena yang dilihat kini adalah berupa realitas yang dihadapkan kepada manusia.

Jean Baudrillard (Reims, 20 Juni 1929-Paris, 6 Maret 2007) adalah seorang pakar teori kebudayaan, filsuf, komentator politik, sosiolog dan fotografer asal Perancis. Karya Baudrillard seringkali dikaitkan dengan pascamodernisme dan pascastrukturialisme. Ia merupakan seorang teoritisi sosial pasca-struktural terpenting. Dalam lingkup tertentu dekade 1980-an, Baudrillard dikenal sebagai McLuhan baru atau teoritisi terkemuka tentang media dan masyarakat dalam era yang disebut juga posmodern. Teorinya mengenai masyarakat posmodern berdasarkan asumsi utama bahwa media, simulasi, dan apa yang ia sebut 'cyberblitz' telah mengkonstitusi bidang pengalaman baru, tahapan sejarah dan tipe masyarakat yang baru.
Penulis menggunakan pemikiran ontology Baudrillard tentang realitas untuk melihat fenomena berpolitik Indonesia karena penulis melihat banyak sekali berita yang dihadapkan ke rakyat Indonesia yang kadang-kadang tidak hanya satu pemahaman bahkan banyak realita yang dipaparkan berlawanan antara satu dengan yang lainnya.

Berdasarkan hal di atas, penulis memunculkan beberapa rumusan masalah yaitu :

1. Apakah realitas itu?

2. Bagaimanakah pemikiran Baudrillard mengenai realitas?

3. Bagaimanakah kontribusi pemikiran Baudrillard dalam melihat realitas kehidupan berpolitik di Indonesia?

\section{PEMBAHASAN \\ Pengertian Realitas}

Sebelum membahas lebih lanjut mengenai pemahaman Baudrillard, penulis akan menjabarkan terlebih dahulu pengertian dari realitas. Menurut Anton Bakker, dalam realitas terdapat dua aliran pokok yaitu realitas bersifat spiritualis yang lepas dari nafsu dan realitas yang bersifat materialis yang merupakan kebalikan dari spiritualis (Bakker, 1992: 177). Dan pemikiran Baudrillard termasuk realitas yang materialis, tapi penulis tidak akan tergesa- gesa mengambil kesimpulan demikian karena pemikiran tokoh postmodern memiliki kecenderungan yang berbeda dengan pemikiran tokoh-tokoh sebelumnya

\section{Pemikiran Baudrillard perspektif reali- tas Anton Bakker}

Filosofi Baudrillard terpusat pada dua konsep "hyperreality" dan "simulation". Terminologi ini mengacu pada alam yang tidak nyata dan khayal dalam kebudayaan kontemporer pada zaman komunikasi massa dan konsumsi massa.

Simulasi adalah proses penciptaan bentuk nyata melalui model-model yang tidak mempunyai asal-usul atau referensi 
realitasnya sehingga memampukan manusia membuat yang supernatural, ilusi, fantasi, khayali menjadi tampak nyata (Piliang, 2004 : 21). Era simulasi sangat mewarnai interaksi social dewasa ini. Simulacrum tidak pernah merupakan suatu yang menyembunyikan kebenaran namun merupakan kebenaran yang menyembunyikan bahwa tidak ada apa-apa. Simulacrum adalah benar. Simulacrum adalah penampakan yan menyatakan diri sebagai realitas.

Ada empat tahap dalam simulasi yaitu representasi ketika citra menjadi cermin suatu realitas, ideology dipahami ketika citra menyembunyikan dan memberi gambar yang salah akan realitas, citra menyembunyikan bahwa tidak ada realitas sehingga citra bermain menjadi penampakannya, citra tidak ada hubungan sama sekali dengan realitas apapun (Haryatmoko, 2010: 24).

Dalam buku Simulacra and Simulations dinyatakan bahwa : The simulacrum is never what hides the truth - it is truth that hides the fact that there is none. The simulacrum is true (Baudrillard, 1981: 1). Simulacrum adalah sebuah duplikasi dari duplikasi, yang aslinya tidak pernah ada, sehingga perbedaan antara duplikasi dan asli menjadi kabur (Piliang, 2004 : 21). Dengan kata lain kumpulan dari simulacra-simulacra dengan simulacra yang membuat simulacra kembali akan memberntuk simulacrum. Baudrillard menjelaskan tiga order penampakan (appearance) yaitu counterfeit, production, simulation, hanya dua order pertama (counterfeit, production) yang dimaknainya secara eksplisit sebagai simulacrum yaitu ketika sesuatu meniru, mengkopi, menduplikasi atau mereproduksi sesuatu yang lain sebagai modelnya (Piliang, 2004: 58) Dalam rangka penggalangan opini dan pencitraan diri, polotisi mengerahkan semua sarana persuasi dari bentuk yang paling transparan, yaitu representasi, sampai dengan manipulasi dan simulasi (Baudrillard, 1981: 17)

Mengenai hyperrealitas Baudrillad menyatakan bahwa :

Never again will the real have the chance to produce itself -such is the vital function of the model in a system of death, or rather of anticipated resurrection, that no longer even gives the event of death a chance. A hyperrealhenceforth sheltered from the imaginary, and from any distinction between the real and the imaginary, leaving room only for the orbital recurrence of models and for the simulated generation of differences (Baudrillard, 1981: 2).

Tidak pernah lagi nyata memiliki kesempatan untuk menghasilkan diri sendiri - hal tersebut adalah fungsi penting dari model dalam sistem kematian, atau lebih tepatnya kebangkitan yang diantisipasi, bahwa tidak ada lagi bahkan memberikan hal kematian kesempatan. Sebuah HyperReal selanjutnya terlindung dari khayalan, dan dari setiap perbedaan antara yang nyata dan yang imajiner, meninggalkan ruang hanya untuk kekambuhan orbit model dan untuk simulasi generasi perbedaan. Baudrillard mengatakan bahwa "hari ini realitas itu sendiri sebagai hiperrealis". Dalam artian bahwa tidak ada lagi yang lebih realitas, karena semua yang kita diami adalah hiperrealitas (Ritzer, 2003: 163). Sehingga realitas yang dihadapkan kepada manusia sekarang ini hanya berupa realitas palsu.

\section{Pemikiran Baudrillard dalam melihat realitas kehidupan berpolitik di Indone- sia}

Pemikiran Baudrillad hanya mampu memberikan penjabaran dari adanya sebuah simulacra yang memungkinkan memunculkan suatu hipereality dan tidak memberikan suatu solusi ataupun cara untuk menolaknya, karena hal tersebut tidak dapat dibatasi keberadaannya. Manusia yang dihadapkan pada sebuah simulacra hanya dihadapkan dengan model-model simulacra dan seringnya tanpa sadar manusia menganggap dan membawanya pada tataran hiperealitas. Pencitraan mendiskualifikasi kategori kebenaran sehingga tidak bisa lagi dibedakan antara realitas, representasi, simulasi, kepalsuan dan hiperrealitas (Baudrillard, 1981: 17)

Hiperealitas menciptakan satu kondisi yang di dalamnya kepalsuan berbaur dengan keaslian; masa lalu berbaur masa kini; fakta bersimpang siur dengan rekayasa; tanda melebur dengan realitas; dusta bersenyawa dengan kebenaran. Kategori-kategori kebenaran, kepalsuan, keaslian, isu, realitas seakan-akan tidak berlaku lagi di dalam dunia seperti itu.

Keadaan dari hiperrealitas ini membuat masyarakat modern ini menjadi berlebihan dalam pola mengkonsumsi sesuatu 
yang tidak jelas esensinya. Kebanyakan dari masyarakat ini mengkonsumsi bukan karena kebutuhan ekonominya melainkan karena pengaruh model-model dari simulasi yang menyebabkan gaya hidup masyarakat menjadi berbeda. Mereka jadi lebih concern dengan gaya hidupnya dan nilai yang mereka junjung tinggi.

Dalam kehidupan di Indonesia situasi politik yang terjadi adalah rakyat disuguhkan berita-berita yang belum tentu diketahui apakah itu sesuai dengan realitasnya atau hanya merupakan potongan-potongan kejadian yang digabung dan membentuk suatu simulasi dalam pemikiran manusia. contohnya pengakuan presiden yang ingin memberantas korupsi dan justru pemerintah yang merupakan bagian dari kabinetnya melakukan praktek korupsi.

\section{PENUTUP}

Pemikiran Baudrillad hanya mampu memberikan penjabaran dari adanya sebuah simulacra yang memungkinkan memunculkan suatu hipereality dan tidak memberikan suatu solusi ataupun cara untuk menolaknya, karena hal tersebut tidak dapat dibatasi keberadaannya. Manusia yang dihadapkan pada sebuah simulacra hanya dihadapkan dengan model-model simulacra dan seringnya tanpa sadar manusia menganggap dan membawanya pada tataran hiperealitas. Pencitraan mendi- skualifikasi kategori kebenaran sehingga tidak bisa lagi dibedakan antara realitas, representasi, simulasi, kepalsuan dan hiperrealitas

Pemikiran Baudrillard ini relevan bila digunakan untuk melihat realitas kehidupan berpolitik di Indonesia, karena dinamika kehidupan berpolitik di Indonesia banyak menimbulkan berbagai realitas palsu. Beberapa contoh yang menunjukkan bahwa sebenarnya rakyat Indonesia sedang ditunjukkan pencitraan oleh pemerintah yaitu pada saat presiden mengatakan tidak tebang pilih dalam kasus korupsi tapi ketika korupsi terjadi di dalam partai yang dibina oleh presiden dan juga cabinet Indonesia bersatu.

\section{DAFTAR PUSTAKA}

Bakker, Anton. 1992. Ontologi Metafisika Umum. Yogyakarta: Kanisius.

Baudrillard.1981. Simulacra and Simulations. Michigan.

Haryatmoko. 2010. Dominasi Penuh Muslihat. Jakarta: Gramedia Pustaka Utama.

Piliang, Yasraf Amir. 2004. Posrealitas. Yogyakarta : Jalasutra

Ritzer, George. 2003. Teori Sosial Postmodern. Yogyakarta : Kreasi Wacana 